\title{
PERLINDUNGAN HUKUM TERHADAP PEKERJA ANAK DALAM TRANSAKSI PENJUALAN KORAN DI KOTA BATAM
}

\author{
Wulan Mei Firina* \\ Ambrastha Waskitha Justice Lawfirm
}

\begin{abstract}
Indonesia's constitution has been giving absolute protection regarding the employment and decent rights to live for its citizen. Based on that matter, the government and legislature worked together to legalize Law of Republic Indonesia Number 13 Year 2003 regarding Employment where there will be protection regarding the equality of opportunity, as well as the fair treatment for the workers. One of the aspects covered by this law is the welfare of child labor that is stated in article number 68 until 75. Article 68 has established that it is forbidden to employ child labor. Like any other cities in Indonesia, Batam is also partaking in this phenomenon that created a complex and problematic social issue.

The objective of this research is to analyze the construction of the law that protects child labor, as well as the role of the media companies and the government in preventing this issue. The data has been collected by doing unstructured interviews and observation. The research is done in "Jurisdiction Sociologies" method.

The result of the research shows that the jurisdiction commitment of the state is to protect the child labor through the construction of the law that prohibited underage children to work and even if they must, based on the provision of the norms, it is compulsory for them to receive a proper law protection. Media companies as the manufacturers of the newspaper have partaken in this illegal child labor. The governor officials in Batam should have gave the proper protection for the children, be it preventive or repressive.
\end{abstract}

\section{Keyword : Child Labor, Newspaper Seller, Batam.}

\begin{abstract}
Abstrak
Konstitusi Indonesia telah memberikan perlindungan absolut mengenai pekerjaan dan hak-hak yang layak untuk hidup bagi warganya. Berdasarkan hal itu, pemerintah dan legislatif bekerja bersama untuk melegalkan Undang-Undang Republik Indonesia Nomor 13 Tahun 2003 tentang Ketenagakerjaan di mana akan ada perlindungan mengenai kesetaraan kesempatan, serta perlakuan adil bagi pekerja. Salah satu aspek yang dicakup oleh undang-undang ini adalah kesejahteraan pekerja anak yang
\end{abstract}

*Alamat Korespondensi : wulan@exaudigroup.com

JOURNAL OF LAW AND POLICY TRANSFORMATION 
dinyatakan dalam pasal 68 hingga 75. Pasal 68 menetapkan bahwa dilarang mempekerjakan pekerja anak. Seperti kota-kota lain di Indonesia, Batam juga mengambil bagian dalam fenomena ini yang menciptakan masalah sosial yang kompleks dan bermasalah.

Tujuan dari penelitian ini adalah untuk menganalisis konstruksi undangundang yang melindungi pekerja anak, serta peran perusahaan media dan pemerintah dalam mencegah masalah ini. Data telah dikumpulkan dengan melakukan wawancara dan observasi tidak terstruktur. Penelitian ini dilakukan dengan metode "Yurisdiksi Sosiologi".

Hasil penelitian menunjukkan bahwa komitmen yurisdiksi negara adalah untuk melindungi pekerja anak melalui konstruksi undang-undang yang melarang anak-anak di bawah umur untuk bekerja dan bahkan jika mereka harus, berdasarkan ketentuan norma-norma, adalah wajib bagi mereka untuk menerima perlindungan hukum yang tepat. Perusahaan media sebagai produsen surat kabar ikut serta dalam pekerja anak ilegal ini. Pejabat gubernur di Batam seharusnya memberikan perlindungan yang tepat untuk anak-anak, baik itu preventif atau represif.

Kata kunci : Pekerja Anak, Penjual Surat Kabar, Batam.

\section{A. Latar Belakang Masalah}

Negara harus menjamin hak asasi warga Negara dalam konstitusi Negara, sebagai konsekuensi dari Negara kesejahteraan (welfare state ${ }^{1}$ ) yang dianut oleh Indonesia. Salah satu hak asasi (rights) yang harus diakui, dipenuhi dan dijamin oleh Negara adalah hak asasi di bidang ketenagakerjaan $^{2}$, sebagaimana diamanatkan dalam Pasal 27 ayat (2) Undang-Undang Dasar Negara Republik Indonesia tahun 1945 (UUDNRI 1945) yang menyatakan "Tiap-tiap warga negara berhak atas pekerjaan dan penghidupan yang layak bagi kemanusiaan".

Konstitusi Indonesia pada dasarnya telah memberikan perlindungan yang menyeluruh atas pekerjaan dan penghidupan yang layak bagi warga Negara. Berdasarkan hal tersebut maka pemerintah bersama-sama badan legislatif membuat Undang-Undang Republik Indonesia Nomor 13 Tahun 2003 tentang Ketenagakerjaan $\left(\mathrm{UUK}^{3}\right)$ dimana perlindungan terhadap tenaga kerja ${ }^{4}$ dimaksudkan untuk menjamin kesamaan kesempatan (equality of opportunity) serta perlakuan tanpa diskriminasi atas dasar apapun untuk

\footnotetext{
${ }^{1}$ Welfare state Miftachul Huda, 2009, Pekerjaan Sosial dan Kesejahteraan Sosial, Sebuah Pengantar, Pustaka Pelajar, Yogyakarta, Hlm. 73

2 Ketenagakerjaan menurut Pasal 1, Undang-Undang Nomor 13 Tahun 2003 tentang Ketenagakerjaan

${ }^{3}$ Undang-Undang Republik Indonesia Nomor 13 Tahun 2003 (Lembaran Negara Republik Indonesia Tahun 2003 Nomor 39, Tambahan Lembaran Negara Republik Indonesia Nomor 4279)

4 Tenaga kerja menurut Pasal 1, Undang-Undang Republik Indonesia Nomor 13 Tahun 2003
} 
mewujudkan kesejahteraan (welfare) pekerja/buruh ${ }^{5}$ dan keluarganya dengan tetap memperhatikan perkembangan dan kemajuan dunia usaha. Salah satu aspek yang diatur oleh UUK ini adalah menyangkut perlindungan hukum terhadap pengupahan, dan kesejahteraan pekerja anak (child labour) sebagaimana tercantum dalam Pasal 68 sampai dengan Pasal 75. Ketentuan Pasal 68 menentukan bahwa pengusaha dilarang mempekerjakan anak.

Seperti halnya dengan kota-kota lain di Indonesia, Kota Batam juga tidak luput dari fenomena pekerja anak yang dewasa ini menjadi problema sosial yang cukup kompleks. Fenomena pekerja anak di bawah umur, saat ini menjadi permasalahan yang sulit diatasi, adapun latar belakang yang menyebabkan mereka menjadi pekerja anak, yang pasti dalam bekerja mereka mempunyai motivasi masing-masing. Motivasi erat kaitannya dengan kebutuhannya, bahkan motivasi timbul karena adanya kebutuhan. ${ }^{6}$

Salah satu hal yang mendorong fenomena pekerja anak adalah semakin tingginya angka kemiskinan. Di Kota Batam angka kemiskinan semakin meningkat dari tahun ke tahun. Menurut data Badan Pusat Statistik Kepulauan Riau, jumlah penduduk miskin pada tahun 2008 mencapai 41.390 orang per tahun, tahun 2009 sebesar 54.777 orang per tahun, sedangkan tahun 2010 mengalami kenaikin yang cukup signifikan yaitu 68.748 orang per tahun. ${ }^{7}$ Hal ini mendorong munculnya pekerja anak dalam bentuk yang sangat exploitatif.

Dinas Sosial dan Pemakaman Kota Batam mencatat, hingga awal 2014 setidaknya terdapat sekitar 200 (dua ratus) anak jalanan berkeliaran di jalanjalan. ${ }^{8}$ Bertambahnya anak jalanan dan pengemis di Batam disebabkan banyaknya pendatang yang menggantungkan hidupnya untuk mencari nafkah hanya dengan modal nekat, melihat Batam yang berkembang, mereka yang tidak memiliki pendidikan yang cukup juga ikut datang dengan mengharapkan pekerjaan yang layak. Namun kenyataan tidak semudah yang mereka bayangkan. Sehingga, banyak yang jadi pemulung dan anaknya turun ke jalan. Pengaruh besar ini dimanfaatkan oleh agen-agen perusahaan media cetak untuk mempekerjakan anak menjual koran di pinggiran jalan. Memang perusahaan tidak memaksa anak untuk bekerja menjual koran yang diprodusi oleh perusahaan media cetak. Namun secara tidak langsung, mereka memanfaatkan peluang anak yang berada dalam kondisi ekonomi yang tidak menguntungkan.

Dengan melihat kenyataan kondisi pekerja anak sebagai penjual koran yang ada di Kota Batam yang sangat jauh berbeda dari hak-hak yang

\footnotetext{
${ }^{5}$ Pekerja/Buruh menurut Pasal 1, Undang-Undang Republik Indonesia Nomor 13 Tahun 2003 tentang Ketenagakerjaan

${ }^{6}$ Abu Ahmadi, 1999, Psikologi Sosial, Rineka Cipta, Jakarta, Hlm. 191

${ }^{7}$ Jumlah Penduduk Miskin per Kab./Kota, 2007 - 2011, (Jiwa) http://kepri.bps.go.id/tabel/ tabeltersimpan?kode=106, diakses tanggal 22 Oktober 2014

${ }^{8}$ Widodo, Anak Jalanan Berkeliaran di Batam, http://www.batamtoday.com/berita39068Setidaknya-200-an-Anak-Jalanan-Berkeliaran-di-Batam.html, diakses tanggal 22 Oktober 2014
} 
seharusnya mereka dapat, yang tidak sesuai dengan Undang-Undang Ketenagakerjaan \& Undang-Undang Perlindungan Anak, maka peneliti tertarik untuk menuangkannya dalam bentuk penelitian yang berjudul "Perlindungan Hukum terhadap Pekerja Anak dalam Transaksi Penjualan Koran di Kota Batam".

\section{B. Rumusan Masalah}

1. Bagaimana konstruksi perlindungan hukum terhadap pekerja anak di Indonesia?

2. Bagaimana peran perusahaan media cetak terhadap adanya pekerja anak?

3. Bagaimana peran pemerintah Kota Batam mencegah adanya pekerja anak?

\section{Metode Penelitian}

Untuk menganalisis permasalahan diatas, penelitian ini dilakukan dengan metode pendekatan Yuridis Sosiologis yang ditujukan terhadap kenyataan dengan cara melihat penerapan hukum (Das Sein), dalam hal ini UU Nomor 23 Tahun 2002 tentang Perlindungan Anak sebagaimana diubah dengan UU Nomor 35 Tahun 2014 dan UU Nomor 13 Tahun 2003 tentang Ketenagakerjan. Peneliti memilih jenis penelitian hukum ini karena peneliti melihat adanya kesenjangan antara aturan hukum yang dikehendaki (Das Sollen) dengan realita yang terjadi (Das Sein) di seputar kehidupan pekerja anak dalam transaksi penjualan koran di Kota Batam.

Penelitian dilakukan di Kota Batam dengan jumlah pekerja anak dalam transaksi penjualan koran kurang lebih 200 (dua ratus) orang menurut data dari Dinas Sosial dan Pemakaman Kota Batam ${ }^{9}$ dari jumlah tersebut diambil sample khususnya di perempatan jalan-jalan utama Kota Batam (Simpang Masjid Raya Batam Centre, Simpang Jam, Simpang Kabil, Simpang Sungai Panas, Simpang Sekupang, dan Simpang Nagoya), pemilihan sampel dilakukan secara purposive sampling ${ }^{10}$, masing-masing simpang sebanyak 4 orang pekerja anak. Penentuan sampel didasarkan atas pertimbangan bahwa jenis pekerjaan maupun umur anak yang bekerja memiliki karakter yang hampir tidak berbeda jauh atau cenderung homogen, sehingga sampel tersebut sudah dianggap cukup mewakili pekerja anak yang berada di wilayah objek penelitian. Teknik pengumpulan data dilakukan dengan wawancara, observasi dan studi dokumen.

Data yang diperoleh dalam penelitian ini dianalisis secara yuridis kualitatif dengan menggunakan metode berpikir deduktif (umum-khusus). Analisis mengenai permasalahan yang diangkat dalam penelitian ini, dilakukan dengan cara menganalisis permasalahan yang ada di lapangan

${ }^{9} \mathrm{http}: / / w w w . b a t a m t o d a y . c o m / b e r i t a 39068-S e t i d a k n y a-200-a n-A n a k-J a l a n a n-B e r k e l i a r a n-$ di-Batam.html, diakses tanggal 22 Oktober 2014

${ }^{10}$ Purposive sampling, Sugiyono, 2008, Metode Penelitian Kuantitatif Kualitatif dan R\&D, Alfabeta, Bandung, Hlm. 218 
yakni mengenai pekerja anak dalam transaksi penjualan koran, selanjutnya akan dikaji dengan dikaitkan dengan peraturan perundang-undangan yang berlaku yaitu pasal 64 Undang-Undang Republik Indonesia Nomor 39 Tahun 1999 tentang Hak asasi Manusia, Pasal 13 ayat (1) Undang-Undang Republik Indonesia Nomor 23 Tahun 2002 tentang Perlindungan Anak sebagaimana diubah dengan Undang-Undang Republik Indonesia Nomor 35 Tahun 2014, dan pasal 68 Undang-Undang Republik Indonesia Nomor 13 Tahun 2003 tentang Ketenagakerjaan dan berkaitan dengan perlindungan hukum pekerja anak di sektor informal sebagai penjaja koran, berkaitan dengan adanya kesenjangan antara hukum normatif (Das Sollen) dengan pelaksanaan norma-norma hukum (Das Sein) di dalam kehidupan masyarakat, yang dalam hal ini hukum dikonsepsikan secara sosiologi sebagai suatu gejala empiris yang dapat diamati dalam kehidupan. Setelah analisis selesai, maka hasilnya akan disajikan secara narasi deskriptif, yaitu dengan cara menguraikan temuan dilapangan sesuai dengan permasalahan yang diteliti. Kemudian ditarik kesimpulan yang merupakan jawaban atas permasalahan yang diangkat dalam penelitian ini.

\section{Hasil Penelitian dan Pembahasan}

\section{Konstruksi Perlindungan Hukum Terhadap Pekerja Anak di Indonesia}

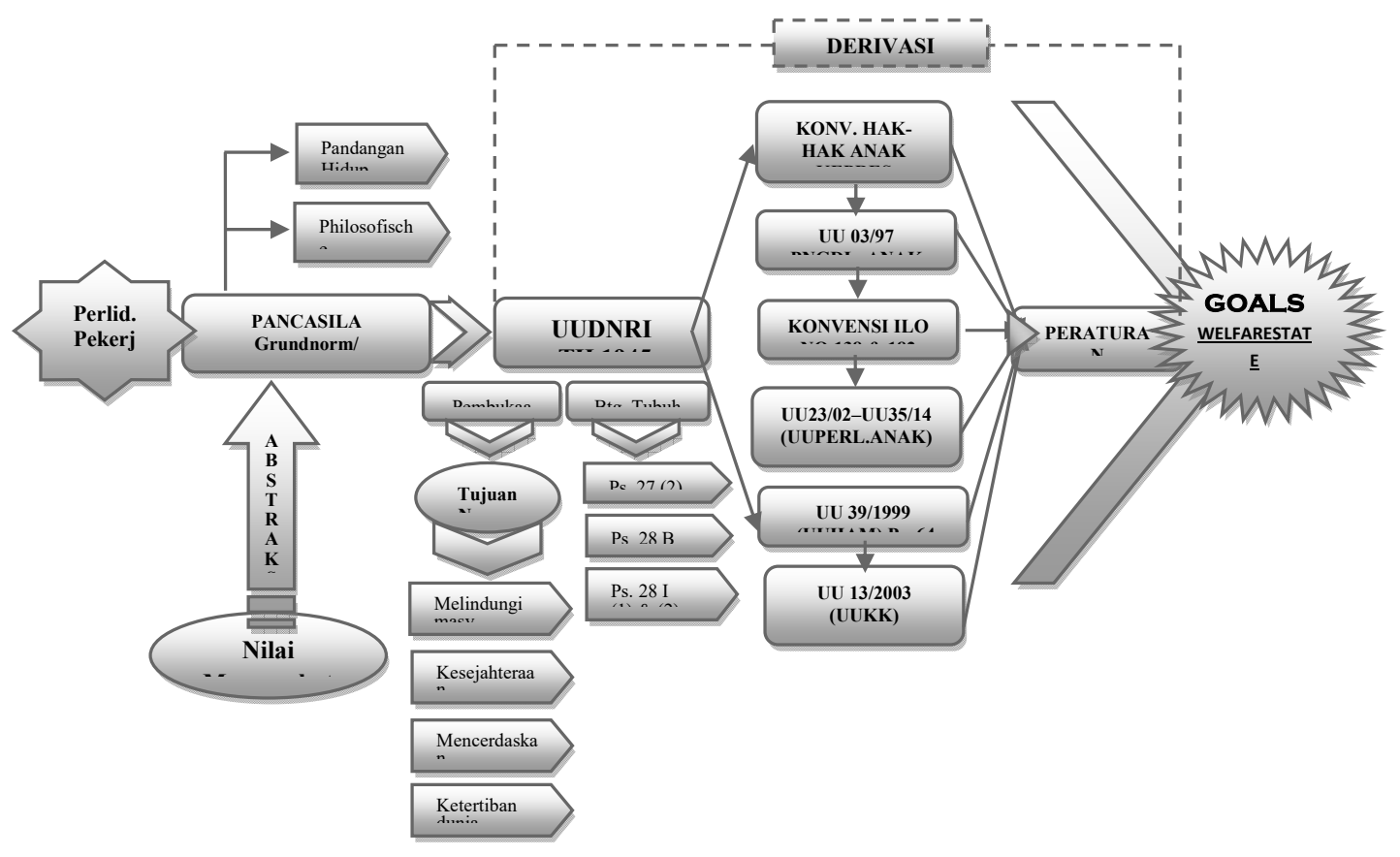

Gambar Konstruksi Perlindungan Hukum Terhadap Pekerja Anak di Indonesia 
Perlindungan hukum merupakan suatu unsur yang terpenting dan wajib ada dalam suatu Negara. Dianggap penting karena di dalam pembentukan suatu Negara pasti terdapat hukum untuk mengatur warga negaranya. Perlindungan Hukum adalah memberikan pengayoman kepada hak asasi manusia yang dirugikan orang lain dan perlindungan tersebut diberikan kepada masyarakat agar mereka dapat menikmati semua hak-hak yang diberikan oleh hukum. ${ }^{11}$ Dalam merumuskan konstruksi perlindungan hukum terhadap pekerja anak di Indonesia, landasannya adalah Pancasila sebagai Staatsfundamentalnorm. Pancasila dilihat sebagai cita hukum (rechsidee), posisi ini mengharuskan pembentukan hukum positif (ius constitutum) adalah untuk mencapai ide-ide dalam Pancasila.

Hal ini sejalan dengan Teori Perlindungan Hukum yang dikemukakan oleh Philiphus M. Hadjon, bahwa Negara Indonesia sebagai negara hukum berdasarkan Pancasila haruslah memberikan perlindungan hukum terhadap warga negara sesuai dengan Pancasila. Oleh karena itu perlindungan hukum berdasarkan Pancasila berarti pengakuan dan perlindungan hukum akan harkat dan martabat manusia atas dasar nilai Ketuhanan Yang Maha Esa, kemanusiaan, persatuan, permusyawaratan, serta keadilan sosial. Nilai-nilai tersebut melahirkan pengakuan dan perlindungan hak asasi manusia dalam wadah negara kesatuan yang menjunjung tinggi semangat kekeluargaan dalam mencapai kesejahteraan bersama. ${ }^{12}$

Dengan ditetapkannya Pancasila sebagai Staatsfundamentalnorm maka pembentukan hukum, penerapan, dan pelaksanaannya tidak dapat dilepaskan dari nilai-nilai Pancasila. Pancasila merupakan abstraksi dari nilai-nilai yang tumbuh dan berkembang di masyarakat. Pancasila lahir dan dirumuskan dalam persidangan Badan Penyelidik Usaha Persiapan Kemerdekaan Indonesia (BPUPKI) pada saat membahas dasar negara, khususnya dalam pidato Soekarno pada tanggal 1 Juni 1945, Soekarno menyebut dasar negara sebagai Philosofische Groundslag sebagai fundamen, filsafat, pikiran yang sedalam-dalamnya yang diatasnya akan didirikan bangunan negara Indonesia. Soekarno juga menyebutnya dengan istilah Weltanschauung atau pandangan hidup. ${ }^{13}$

Pancasila adalah cerminan nilai-nilai kehidupan Indonesia sejak jaman nenek moyang sampai dewasa ini. Berdasarkan hal tersebut terdapatlah perbedaan antara masyarakat Indonesia dengan masyarakat lain. Nilai-nilai kehidupan tersebut mewujudkan amal perbuatan dan pembawaan serta watak orang Indonesia, dengan kata lain masyarakat Indonesia mempunyai ciri sendiri, yang merupakan kepribadiannya. Dengan nilai-nilai

${ }^{11}$ Satjipto Raharjo, Penyelenggaraan Keadilan dalam Masyarakat yang Sedang Berubah, Jurnal Masalah Hukum, 1993, Hlm.121

12 Philipus M. Hadjon, 1987, Perlindungan Hukum Bagi Rakyat Indonesia, PT. Bina Ilmu, 1987, Surabaya, Hlm.84.

13 Saafroedin Bahar, dkk., Risalah Sidang Badan Penyelidik Usaha-Usaha Persiapan Kemerdekaan (BPUPKI), Panitia Persiapan Kemerdekaan Indonesia (PPKI) 28 Mei 1945 - 33 Agustus 1945, Jakarta: Sekretariat Negara Republik Indonesia, 1995, hlm.63 
pulanglah rakyat Indonesia melihat dan memecahkan masalah kehidupan ini untuk mengarahkan dan mempedomani dalam kegiatan kehidupannya bermasyarakat. Demikianlah mereka melaksanakan kehidupan yang diyakini kebenarannya. Itulah pandangan hidupnya karena keyakinan yang telah mendarah daging itulah maka Pancasila dijadikan dasar negara serta ideologi negara. ${ }^{14}$

Untuk mewujudkan masyarakat Pancasila, diperlukan suatu hukum yang berisi norma-norma, aturan-aturan atau ketentuan-ketentuan yang harus dilaksanakan dan ditaati oleh setiap warga negara Indonesia. Hukum yang dimaksud yaitu Undang-Undang Dasar Negara Republik Indonesia Tahun 1945 (UUDNRI 1945) sebagai hukum dasar tertulis di negara kita. Pancasila sebagai dasar negara Republik Indonesia ditetapkan pada tanggal 18 Agustus 1945, sebagai dasar negara, maka nilai-nilai kehidupan bernegara dan berpemerintahan sejak saat itu haruslah berdasarkan pada Pancasila. ${ }^{15}$

Dalam sudut pandang kenegaraan, komitmen negara untuk melindungi warga negaranya termasuk didalamnya terhadap pekerja anak, dapat ditemukan dalam Pembukaan UUDNRI 1945, yang tercermin dalam kalimat:

"Kemudian dari pada itu untuk membentuk suatu Pemerintah Negara Indonesia yang melindungi segenap bangsa Indonesia dan seluruh tumpah darah Indonesia dan untuk memajukan kesejahteraan umum, mencerdaskan kehidupan bangsa, dan ikut melaksanakan ketertiban dunia yang berdasarkan kemerdekaan, perdamaian abadi dan keadilan sosial, maka disusunlah Kemerdekaan Kebangsaan Indonesia itu....".

Masalah perlindungan anak adalah sesuatu yang kompleks dan menimbulkan berbagai macam permasalahan lebih lanjut, yang tidak selalu dapat diatasi secara perseorangan, tetapi harus secara bersama-sama, dan penyelesaiannya menjadi tanggungjawab bersama. Menurut Arif Gosita bahwa perlindungan anak adalah suatu hasil interaksi karena adanya interrelasi antara fenomena yang ada dan saling mempengaruhi. Oleh sebab itu, apabila kita mau mengetahui adanya, terjadinya pelindungan anak yang baik atau buruk, tepat atau tidak tepat, maka kita harus memperhatikan fenomena mana yang relevan, yang mempunyai peran penting dalam terjadinya kegiatan perlindungan anak. ${ }^{16}$

Dalam rangka mengembangkan usaha kegiatan perlindungan anak ini, maka pemerintah Indonesia sejak tahun 1990 telah meratifikasi Konvensi Hak Anak (KHA) melalui Keputusan Presiden Nomor 36 Tahun 1990. Ratifikasi ini merupakan tonggak awal dari perlindungan anak di Indonesia. Selanjutnya, pasca diratifikasinya konvensi ini, disusun berbagai

${ }^{14}$ Firdaus, 2010, Pancasila, Suska Pers, Pekanbaru, Hlm. 1

${ }^{15}$ Ibid.,

${ }^{16}$ Arif Gosita, 1989, Masalah Perlindungan Anak, Akademika Presindo, Jakarta, Hlm. 12 
upaya untuk memetakan berbagai persoalan anak, baik dilakukan oleh pemerintah maupun bekerjasama dengan berbagai lembaga PBB yang memiliki mandat untuk melaksanakan perlindungan anak.

Selanjutnya pada tahun 1997, Indonesia telah memiliki UndangUndang khusus yang mengatur mengenai masalah anak yang berkonflik dengan hukum, yaitu Undang-Undang Nomor 3 Tahun 1979 tentang Pengadilan Anak, memberikan perhatian dan spesifikasi khusus bagi anakanak yang disangka melakukan tindak pidana. Undang-undang ini juga memberikan kekhususan, baik dalam penyidikan, penahanan, penuntutan, peradilan, hingga penempatan di lembaga pemasyarakatan anak.

Sebagai puncak dari upaya legislasi adalah lahirnya Undang-Undang Republik Indonesia Nomor 23 Tahun 2002 tentang Perlindungan Anak (UU Perlindungan Anak), sebagaimana diubah dengan Undang-Undang Republik Indonesia Nomor 35 Tahun 2014 tentang Perubahan Undang-Undang Nomor 23 Tahun 2002 tentang Perlindungan Anak (UU 35/2014 tentang Perubahan UU Perlindungan Anak), memberikan peralatan yang kuat untuk mengimplementasikan Konvensi Hak Anak (KHA) di Indonesia.

Perlindungan hukum terhadap pekerja anak tidak dapat terpisah dengan hak asasi anak, sebab secara konstitusional Indonesia telah mengakui hak untuk bekerja dalam Pasal UUDNRI 1945 yang dimasukkan pada klasifikasi hak yang bersifat asasi. Perlindungan Hukum terhadap pekeja anak juga dituangkan dalam Undang-Undang Nomor 39 Tahun 1999 tentang Hak Asasi Manusia (UU HAM) Pasal 64 mengatur mengenai perlindungan anak dari eksploitasi ekomoni, yaitu:

"Setiap anak berhak untuk memperoleh perlindungan dari kegiatan eksploitasi ekonomi dan setiap pekerjaan yang membahayakan dirinya, sehingga dapat mengganggu pendidikan, kesehatan fisik, moral, kehidupan sosial, dan mental spiritualnya."

Pendekatan perlindungan, muncul berdasarkan pandangan bahwa anak sebagai individu mempunyai hak untuk bekerja. Oleh karena itu hak-hak anak sebagai pekerja harus dijamin melalui peraturan ketenagakerjaan yaitu Undang-Udang Nomor 13 Tahun 2003 tentang Ketenagakerjaan (UU Ketenagakerjaan) sebagaimana yang berlaku bagi pekerja dewasa, sehingga pekerja anak akan terhindar dari tindak penyalahgunaan dan eksploitasi. Perlindungan pekerja anak di dalam UU Ketenagakerjaan termuat dalam Pasal 68 sampai dengan Pasal 75.

Walaupun belum ada peraturan perundang-undangan yang secara spesifik dan komprehensif melindungi pekerja anak di Indonesia, akan tetapi terdapat beberapa peraturan perundang-undangan serta perturan pelaksananya yang dapat digunakan sebagai landasan kebijakan guna melindungi pekerja anak di Indonesia untuk mencapai tujuan Negara sebagai Negara kesejahteraan (Welfare State).

2. Peran Perusahaan Media Cetak Terhadap Adanya Pekerja Anak dalam Transaksi Penjualan Koran 
Umumnya praktek memperkerjakan anak sebagai penjual koran dapat diilutrasikan sebagai berikut:

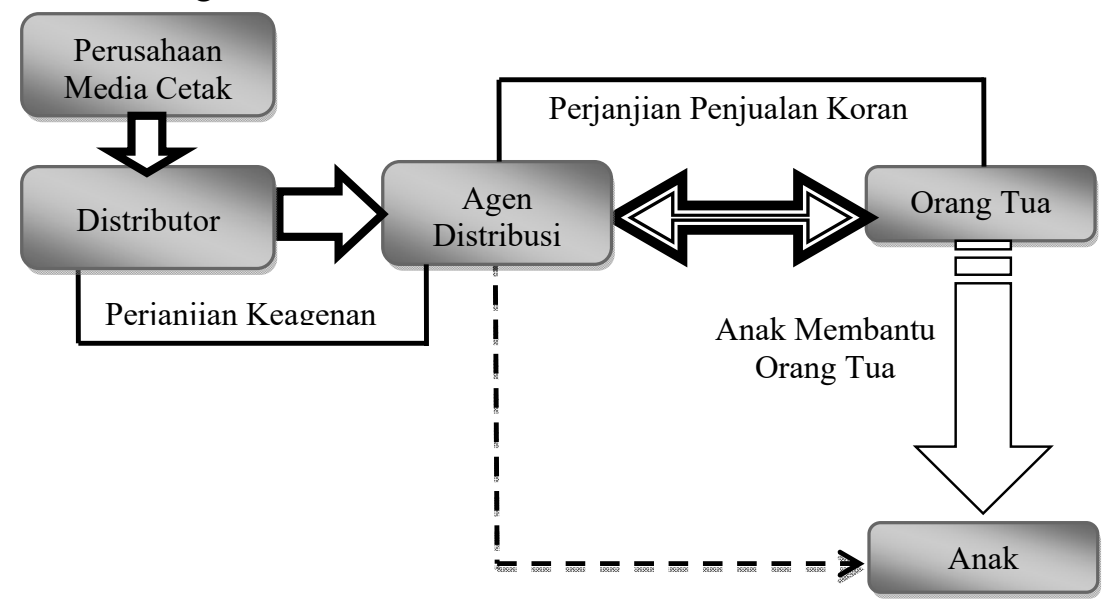

Gambar Alur Praktek Memperkerjakan Anak dalam Transaksi Penjualan Koran

Perusahaan media cetak melalui distributor bekerjasama dengan beberapa agen distribusi. Untuk menjadi agen distribusi harus mengajukan izin kepada distributor resmi yang ditunjuk. Distributor biasanya hanya melayani pembelian dalam jumlah besar saja atau dari agen saja. Sedangkan agen langsung menjualnya surat kabar secara eceran langsung kepada konsumen. Jika agen dianggap mampu dan memenuhi persyaratan serta lulus kualifikasi menjadi agen maka barulah agen tersebut bisa beroperasi.

Pada umumnya, dalam penjulan koran sampai ke tangan pembaca, agen distribusi bisa memperkerjakan sub-agen, loper koran, maupun pengecer. Di agen-agen, keramaian berlangsung antara pukul 04:00 dan 06:00 pagi oleh para sub-agen, loper, dan pengecer yang mengambil jatah mereka. Jatah koran untuk para sub-agen diantarkan langsung oleh agen, kemudian dari sub-agen, koran tiba ke tangan pengecer dan kemudian pembaca. Untuk jatah loper, pada umumnya sudah mempunyai pelanggan tetap sehingga loper koran hanya bertugas mengantarkan saja. Sedangkan jatah untuk pengecer yang mangkal di sejumlah persimpangan lampu merah dikirimi langsung oleh armada dari agen. Di Simpang Jam misalnya, saban pagi koran-koran itu ditaruh begitu saja ditumpuk dibawah pohon hingga pengecernya datang, memilah-milah, dan siap menjajakannya. Tidak jarang terlihat segerombol anak-anak dalam fenomena memilah-milah tumpukan koran ini, yang kemudian langsung menjajakannya di simpang lampu merah. Segorombolan anak dalam fenomena tersebut umumnya berumur 513 Tahun, sehingga anak yang bekerja dibawah 13 tahun juga disebut pekerja anak.

Dalam kasus pekerja anak dalam transaksi penjualan koran berdasarkan skema tersebut diatas, makapenulis menganalisa sebagai berikut: 
Perjanjian merupakan suatu perbuatan yaitu perbuatan hukum (perbuatan yang mempunyai akibat hukum) dengan mana satu orang atau lebih mengikatkan dirinya terhadap satu orang lain atau lebih (Pasal 1313 KUHPerdata). Perjanjian juga dapat dikatakan sebagai perbuatan untuk memperoleh seperangkat hak dan melaksanakan kewajiban yaitu akibatakibat hukum yang merupakan konsekuensinya. Pengertian perjanjian ini mengandung unsur:

1) Perbuatan, yaitu perbuatan hukum atau tindakan hukum, karena perbuatan tersebut membawa akibat hukum bagi para pihak yang memperjanjikan;

2) Satu orang atau lebih, untuk adanya suatu perjanjian, paling sedikit harus ada dua pihak yang saling berhadap-hadapan dan saling memberikan pernyataan yang cocok atau pas satu sama lain. Pihak tersebut adalah orang atau badan hukum;

3) Mengikatkan dirinya, di dalam perjanjian terdapat unsur janji yang diberikan oleh pihak yang satu kepada pihak yang lain. Dalam perjanjian ini orang terikat kepada akibat hukum yang muncul karena kehendaknya sendiri.

Agar suatu perjanjian dapat menjadi sah dan mengikat para pihak, perjanjian harus memenuhi syarat-syarat sebagaimana ditetapkan dalam Pasal 1320 KUHPerdata yang menentukan adanya 4 (empat ) syarat sahnya suatu perjanjian, pertama, adanya kata sepakat bagi mereka yang mengikatkan dirinya; kedua, kecakapan para pihak untuk membuat suatu perikatan; ketiga, suatu hal tertentu; dan keempat, suatu sebab (causa) yang halal.

Persyaratan tersebut diatas berkenan baik mengenai subjek maupun objek perjanjian. Persyaratan yang pertama dan kedua berkenan dengan subjek perjanjian atau syarat subjektif. Persyaratan yang ketiga dan keempat berkenan dengan objek perjanjian atau syarat objektif. Pembedaan kedua persyaratan tersebut dikaitkan pula dengan masalah batal demi hukumnya (nieteg atau null and $a b$ initio) dan dapat dibatalkannya (vernietigbaar = voidable) suatu perjanjian. Apabila syarat objektif dalam perjanjian tidak terpenuhi maka Perjanjian tersebut batal demi hukum atau perjanjian yang sejak semula sudah batal, hukum menganggap perjanjian tersebut tidak pernah ada. Apabila syarat subjektif tidak terpenuhi maka Perjanjian tersebut dapat dibatalkan atau sepanjang perjanjian tersebut belum atau tidak dibatalkan pengadilan, maka perjanjian yang bersangkutan masih terus berlaku.

Dalam skema alur transaksi penjualan koran oleh pekerja anak sebagaimana tersebut diatas, peneliti menganalisis dari sisi perjanjian penjualan koran sebagai berikut:

1) Perjanjian penjualan koran antara agen dengan orang tua sebagai pengecer 
Perjanjian dapat dilakukan dengan dua cara yaitu perjanjian secara lisan dan tertulis. Perjanjian secara lisan banyak terjadi dalam pergaulan masyarakat sederhana, serta merta sering tidak disadari namun sudah terjadi kesepakatan, dengan kata lain perjanjian lisan akan menjadi sah apabila hak dan kewajiban dari para pihak telah terpenuhi. Namun yang menjadi permasalahan adalah bagaimana dengan kekuatan mengikat dan pelaksanaan perjanjian yang dibuat secara lisan, serta bagaimana cara membuktikan secara hukum bahwa telah terjadi suatu perjanjian atau kesepakatan yang dibuat oleh para pihak, mengingat perjanjian lisan tidak menggunakan akta otentik dan akta dibawah tangan.

Dalam kasus ini perjanjian antara agen dengan orang tua sebagai pengecer dilakukan secara lisan, agen hanya menawarkan secara lisan kepada pengecer tentang komisi yang didapatkan atas penjualan koran yaitu Rp. 12.000,- per 20 eksemplar koran, dan apabila dalam satu hari seorang pengecer bisa menjual 40 eksemplar, ia akan mendapatkan komisi Rp. 36.000,-. Perjanjian ini dilakukan atas dasar hal yang sangat sederhana yaitu "saling percaya". Dalam perjanjian secara lisan ini tidak secara jelas menyebutkan terkait syarat-syarat pelaksanaan penjualan koran misalnya tentang larangan orang tua sebagai pengecer untuk memperkerjakan anaknya sebagai penjual koran di simpangsimpang lampu merah.

Dalam kasus ini, terdapat ekploitasi terhadap anak yang dalam perkembangannya anak dijadikan sebagai objek perjanjian antara orang tua dengan agen distribusi. Jika dikaitkan dengan syarat sah perjanjian sebagaimana tercantum dalam pasal 1320 KUHPerdata maka unsur suatu hal tertentu dalam perjanjian penjualan koran antara agen distribusi dengan orang tua yaitu anak dianggap suatu benda (zaak) yang diperjanjikan. Benda dalam hal ini tidak hanya berarti barang dalam arti sempit, tetapi juga dalam arti luas yakni jasa sebagai penjual koran yang dilakukan oleh anak. Sedangkan jika dikaitkan dengan unsur kausa hukum yang halal objek yang diperjanjikan antara orang tua dengan agen distribusi dalam bentuk jasa penjualan koran yang dilakukan oleh anak, tidak memenuhi unsur kausa halal, jadi syarat sah perjanjian kausa hukum halal dalam perjanjian ini tidak terpenuhi sehingga perjanjian tersebut batal demi hukum atau dapat dikatakan perjanjian tersebut tidak pernah ada.

2) Perjanjian keagenan antara perusahaan media cetak dengan agen distribusi

Agen distribusi mempunyai peranan sebagai perantara untuk memudahkan penyampaian koran dari produsen ke konsumen. Para pihak dalam membuat perjanjian keagenan biasanya mendasarkan pada asas kebebasan berkontrak sebagaimana yang dianut oleh Pasal 1338 KUHPerdata. 
Seharusnya dengan adanya asas kebebasan berkontrak tersebut, posisi kedua belah pihak adalah sama dan sederajat. Namun, dalam praktek di lapangan sebenarnya kedua pihak tidak dalam posisi yang seimbang. Seringkali terjadi pihak agen harus menerima persyaratanpersyaratan yang diberikan oleh perusahaan media cetak secara mutlak tanpa bisa menawar lagi. Hal ini disebabkan karena perusahaan media cetak telah mempersiapkan standar-standar dalam formulir perjanjian, berarti bagi agen yang ingin mengadakan perjanjian dengan pihak produsen terikat dengan formulir-formulir perjanjian yang sudah disediakan pihak produsen. Adapun hal yang melatarbelakangi dibuatnya suatu standar kontrak adalah untuk mempermudah perusahaan dalam menjalankan usahanya, yang dalam lingkup usahanya perusahaan prinsipal telah mempersiapkan jaringan distribusi produknya tidak secara ekslusif dijalankan oleh satu agen saja, melainkan lebih dari itu. Oleh karenanya untuk mempermudah aspek pemahaman transaksi, pola administrasi dan permasalahan lainnya, maka perusahaan cenderung menjalankan pola pemberlakuan standar perjanjian baku tersebut.

Secara logika dapat digambarkan bahwa isi perjanjian tersebut tidak ada yang mengatur tentang larangan atau memperbolehkan agen untuk memperkerjakan anak dalam transaksi penjualan koran. Logikanya bahwa jika terdapat larangan memperkerjakan anak sudah pasti secara otomatis terdapat sanksi yang tegas jika dilanggar. Hal ini terbuki bahwa adanya pekerja anak dalam transaksi penjualan koran adalah salah satu bentuk pembiaran yang dilakukan oleh perusahaan media cetak, karena tidak ada tindakan tegas dari perusahaan media cetak terhadap agen yang memperkerjakan anak, misalnya pemutusan kerjasamanya keagenan, skorsing dan lain-lain. Dalam hal ini, perusahaan media cetak cenderung melakukan pembiaran dan terkesan pura-pura tidak mengetahui bahwa anak-anak terlibat dalam transaksi penjualan koran.

Disamping itu, apabila di dalam perjanjian kerjasama keagenan, perusahaan media cetak memperbolehkan keterlibatan anak-anak dalam transaksi penjualan koran, maka perusahaan wajib mengatur tata cara memperkerjakan anak dengan mengacu kepada UndangUndang Nomor 13 Tahun 2003 tentang Ketenagakerjaan (UUK) Pasal 68 sampai dengan Pasal 75 beserta peraturan pelaksananya.

Dari sisi perjanjian dalam transaksi penjualan koran oleh pekerja anak, ada atau tidak klausul dalam perjanjian keagenan yang menyatakan memperbolehkan atau melarang untuk memperkerjakan anak dalam transaksi penjualan koran, pada kenyataannya (Das Sein) anak tetap bekerja untuk mejajakan koran di simpang-simpang lampu merah dengan kondisi sebagai berikut : 
Tabel Kondisi Pekerja Anak dalam Transaksi Penjualan Koran

\begin{tabular}{|c|c|c|c|}
\hline No. & Keterangan & Das Sollen & Das Sein \\
\hline 1. & Umur anak & $\begin{array}{l}\text { Pasal } 69 \text { Ayat (1) UU } \\
\text { Ketenagakerjaan, } 13-15 \text { th }\end{array}$ & $5-13$ th \\
\hline 2. & $\begin{array}{l}\text { Ijin dari orang } \\
\text { tua }\end{array}$ & $\begin{array}{l}\text { Pasal } 69 \text { Ayat (2) huruf a } \\
\text { UU Ketenagakerjaan, Ijin } \\
\text { Tertulis }\end{array}$ & Tidak ada ijin \\
\hline 3. & Perjanjian kerja & $\begin{array}{l}\text { Pasal } 69 \text { Ayat (2) huruf b } \\
\text { UU Ketenagakerjaan, } \\
\text { pengusaha dengan orang } \\
\text { tua }\end{array}$ & $\begin{array}{l}\text { Tidak ada } \\
\text { perjanjian kerja }\end{array}$ \\
\hline 4. & Jam kerja & $\begin{array}{ll}\text { Pasal } 69 \text { Ayat (2) huruf c } \\
\text { UU } \\
\text { Jam }\end{array}$ & $\begin{array}{l}\text { Lebih dari } 3 \text { Jam } \\
\text { (5-10 Jam) }\end{array}$ \\
\hline 5. & Waktu kerja & $\begin{array}{l}\text { Pasal } 69 \text { Ayat (2) huruf d } \\
\text { UU Ketenagakerjaan, siang } \\
\text { hari \& tidak menganggu } \\
\text { waktu sekolah }\end{array}$ & $\begin{array}{l}\text { Malam hari, pada } \\
\text { umumnya anak } \\
\text { tidak bersekolah }\end{array}$ \\
\hline 6. & $\begin{array}{l}\text { Keselamatan dan } \\
\text { kesehatan kerja }\end{array}$ & $\begin{array}{l}\text { Pasal } 69 \text { Ayat (2) huruf e } \\
\text { UU Ketenagakerjaan, } \\
\text { Dilindungi }\end{array}$ & $\begin{array}{l}\text { Tidak } \\
\text { dilindungi/Tidak } \\
\text { terjamin }\end{array}$ \\
\hline 7. & Hubungan Kerja & $\begin{array}{l}\text { Pasal } 69 \text { Ayat (2) huruf f } \\
\text { UU Ketenagakerjaan, ada } \\
\text { hubungan kerja yang jelas }\end{array}$ & $\begin{array}{l}\text { Hubungan } \\
\text { tidak jelas }\end{array}$ \\
\hline 8. & Upah & $\begin{array}{l}\text { Pasal } 69 \text { Ayat (2) huruf g } \\
\text { UU Ketenagakerjaan, } \\
\text { sesuai ketentuan UU }\end{array}$ & $\begin{array}{l}\text { Berdasarkan hasil } \\
\text { penjualan dalam } \\
\text { bentuk komisi }\end{array}$ \\
\hline
\end{tabular}

Dari hasil interview dan observasi dapat disimpulkan bahwa terdapat ekploitasi terhadap anak dalam transaksi penjualan koran oleh orang tuanya sendiri, anak dipaksa berjualan ditengah keramaian lalu lintas kendaraan dan orang tuanya hanya duduk-duduk sambil mengawasi, tidak jarang juga ketika si anak tidak berhasil menjual habis jatah koran dagangannya, maka si anak terlihat ketakutan karena akan dipukuli oleh orang tuanya, hal ini sangat bertentangan dengan beberapa peraturan perundang-undangan yang melindungi hak-hak anak yaitu Pasal 64 dan 58 Undang-Undang HAM, Pasal 13 dan Pasal 4 Undang-Undang Perlindungan Anak.

Fenomena eksploitasi anak ini juga tidak hanya dilakukan oleh orang tuanya saja, akan tetapi perusahaan secara tidak langsung juga melakukan pembiaran terhadap eksploitasi anak sehingga perusahaan bisa dikatakan turut serta, karena dalam hal ini perusahaan sangat diuntungkan oleh adanya pekerja anak dalam transaksi penjualan produknya, bagaimana tidak, konsumen (pembaca) cenderung iba melihat anak-anak berjualan koran dan 
berniat untuk membeli, jumlah yang berhasil dijual seorang anak terbukti lebih besar daripada orang dewasa yang menjual, hal ini merupakan keuntungan bagi perusahaan. Karena bagi perusahaan media cetak jumlahkoran yang berhasil terjual (oplah) sangat menentukan kredibilitas perusahaan media cetak, yang dapat menarik minat para pengguna iklan melalui media koran. Perusahaan sebagai pelaku ekonomi yang sebagian besar turut membantu untuk stabilitator perkembangan perekonomian Negara dan begitu juga anak merupakan tunas bangsa untuk kemajuan negara kedepan oleh karena itu segala aktivitas dan upaya untuk memberikan perlindungan untuk mereka adalah tanggungjawab bersama.

Hasil analisis pembahasan tersebut diatas mengukuhkan teori perlindungan hukum yang dikemukanakan oleh Philiphus M. Hadjon menyebutkan bahwa prinsip perlindungan hukum terhadap tindakan pemerintah dalam mencapai kesejahteraan bertumpu dan bersumber dari konsep tentang pengakuan dan perlindungan terhadap hak-hak asasi manusia (dalam penelitian ini hak-hak anak) yang menekankan eksistensi hak yang melekat pada kodrat manusia yang tidak dapat diganggu gugat. Dalam hukum positif tindakan pemerintah dalam melindungi hak-hak asasi pekerja anak tertuang dalam Undang-Undang HAM, Undang-Undang Perlindungan Anak, Undang-Undang Ketenagakerjaan dan peraturan pelaksananya. Tindakan pemerintah ini berorientasi untuk mewujudkan Negara kesejahteraan (welfare state) yang dalam pembahasan ini penulis mengukuhkan teori welfare state yang dikemukakan oleh R. Kranenburg yang menyatakan bahwa Negara harus secara aktif mengupayakan kesejahteraan, bertindak adil yang dapat dirasakan seluruh masyarakat (dalam hal ini pekerja anak) secara merata dan seimbang. Permasalahan yang dihadapi oleh pekerja anak yang tidak mendapatkan jaminan perlindungan hukum dan kesejahteraan dikarenakan pihak-pihak yang memanfaatkan posisi lemah anak untuk mencari keuntungan baik perusahaan media cetak untuk mendongkrak jumlah oplah penjualan koran maupun orang tua yang memperkerjakan anak untuk membantu perekonomian keluarga.

\section{Peran Pemerintah Kota Batam dalam Mencegah Adanya Pekerja Anak}

Perlindungan terhadap anak wajib diusahakan oleh setiap orang baik orang tua, keluarga, masyarakat, pemerintah maupun Negara. Pasal 20 UU 35/2014 tentang Perubahan UU Perlindungan Anak menentukan "Negara, Pemerintah, Pemerintah Daerah, Masyarakat, Keluarga, dan Orang Tua atau Wali berkewajiban dan bertanggung jawab terhadap penyelenggaraan Perlindungan Anak".

Kewajiban dan tanggungjawab Negara dan pemerintah dalam usaha menjamin perlindungan anak diatur dalam Pasal 21 sampai dengan 24 Undang-Undang Nomor 23 Tahun 2002 tentang Perlindungan Anak sebagaimana telah diubah oleh Undang-Undang Nomor 35 Tahin 2014 sebagai berikut: 
1) Negara, Pemerintah, dan Pemerintah Daerah berkewajiban dan bertanggung jawab menghormati pemenuhan Hak Anak tanpa membedakan suku, agama, ras, golongan, jenis kelamin, etnik, budaya dan bahasa, status hukum, urutan kelahiran, dan kondisi fisik dan/atau mental. Untuk menjamin pemenuhan Hak Anak tersebut: ${ }^{17}$

a. Negara berkewajiban untuk memenuhi, melindungi, dan menghormati Hak Anak;

b. Pemerintah berkewajiban dan bertanggung jawab dalam merumuskan dan melaksanakan kebijakan di bidang penyelenggaraan perlindungan anak;

c. Pemerintah Daerah berkewajiban dan bertanggung jawab untuk melaksanakan dan mendukung kebijakan nasional dalam penyelenggaraan Perlindungan Anak di daerah.

2) Negara, Pemerintah, dan Pemerintah Daerah berkewajiban dan bertanggung jawab memberikan dukungan sarana, prasarana, dan ketersediaan sumber daya manusia dalam penyelenggaraan Perlindungan Anak. ${ }^{18}$

3) Negara, Pemerintah, dan Pemerintah Daerah menjamin perlindungan, pemeliharaan, dan kesejahteraan Anak dengan memperhatikan hak dan kewajiban Orang Tua, Wali, atau orang lain yang secara hukum bertanggung jawab terhadap Anak. Negara, Pemerintah, dan Pemerintah Daerah mengawasi penyelenggaraan Perlindungan Anak. ${ }^{19}$

4) Negara, Pemerintah, dan Pemerintah Daerah menjamin Anak untuk mempergunakan haknya dalam menyampaikan pendapat sesuai dengan usia dan tingkat kecerdasan Anak. ${ }^{20}$

Disnaker dan Dinsos Kota Batam sendiri selama ini mengakui bahwa mereka sebenarnya tidak secara langsung mempunyai program khusus untuk menangani pekerja anak. Namun, secara tidak langsung instansi ini memiliki kegiatan pembinaan anak jalan dan anak terlantar. Menurut Kepala Dinsos Kota Batam, tercatat sebanyak 200 pekerja anak penjaja koran yang tersebar di simpang-simpang lampu merah Kota Batam. Kesulitan untuk menangani masalah ini karena pihak Dinsos sendiri belum memiliki data yang akurat tentang profil dan seluk-beluk kehidupan pekerja anak penjaja koran di Batam, terutama setelah jumlah mereka semakin banyak akibat kondisi ekonomi yang semakin melemah.

Menurut informasi yang diperoleh, pendekatan yang dilakukan oleh Dinsos Kota Batam adalah pembinaan kesejahteraan anak yang pelaksanaannya dipusatkan dalam suatu lembaga formal seperti panti sosial atau panti asuhan anak. Sementara itu, rumah singgah adalah suatu tempat

${ }^{17}$ Lihat Pasal 21 Perubahan UU No.23 Tahun 2002 tentang Perlindungan Anak

18 Lihat Pasal 22 Perubahan UU No.23 Tahun 2002 tentang Perlindungan Anak, serta Penjelasan Pasal 22

${ }^{19}$ Lihat Pasal 23 Perubahan UU No.23 Tahun 2002 tentang Perlindungan Anak

${ }^{20}$ Lihat Pasal 24 Perubahan UU No.23 Tahun 2002 tentang Perlindungan Anak 
pemusatan sementara yang bersifat non-formal, dimana anak-anak bertemu untuk memperoleh informasi dan pembinaan awal sebelum dirujuk kedalam proses pembinaan lebih lanjut.

Untuk menangani masalah pekerja anak dalam transaksi penjualan koran di Batam secara tuntas, langkah awal yang dibutuhkan adalah keberanian dan keterbukaan dari semua pihak untuk mengakui bahwa disini keberadaan pekerja anak memang benar-benar nyata agar aparat pemerintah Kota Batam dapat bersikap lebih empatif dan secara kreatif mampu merumuskan program-program penangan yang lebih kontekstual. Dalam proses pengawasan ketenagakerjaan, sosialisasi peraturan perundangundangan merupakan kegiatan awal yang harus dilakukan sebelum melakukan penegakan hukum dan pembinaan serta tindakan lanjutan. Pegawai Pengawas Ketenagakerjaan adalah pegawai negeri sipil Dinas Tenaga Kerja Kota Batam yang ditetapkan oleh Menteri atau pejabat yang ditunjuk, hal ini sebagaimana ketentuan pasal 177 Undang-Undang Nomor 13 tahun 2003 tentang Ketenagakerjaan.

Hasil analisis pembahasan tersebut diatas mengukuhkan teori perlindungan hukum yang dikemukanakan oleh Philiphus M. Hadjon menyebutkan bahwa sarana perlindungan hukum terhadap pekerja anak terdiri dari sarana perlindungan hukum preventif dan represif, dalam penelitian ini perlindungan hukum preventif dan represif dilakukan oleh Pemerintah Kota Batam (Pemko Batam) melalui Dinsos dan Disnaker Kota Batam serta dinas-dinas terkait.

Perlindungan preventif yang dilakukan oleh Pemko Batam hanya sebatas menerapkan peraturan perundang-undangan produk dari pemerintah pusat. Pemko Batam dalam hal ini belum menggunakan kebijakan otonomi daerahnya untuk mengatur secara khusus tentang pelindungan hukum terhadap anak khususnya pekerja anak di Kota Batam. Hal ini disebabkan karena Pemko Batam masih belum memandang bahwa masalah pekerja anak ini merupakan masalah yang urgent hal ini terbukti bahwa sampai dengan saat ini Pemko Batam belum mengesahkan Peraturan Daerah tentang Perlindungan Anak yang sejak tahun 2014 sampai dengan saat ini masih dalam Program Legislasi Daerah (Prolegda). Sehingga dalam hal ini Pemko Batam belum memiliki sarana hukum (yuridis instrument) yang mengatur tentang bagaimana tata cara penyelesaian terhadap penyimpangan tehadap pekerja anak. Pemerintah mempunyai peran yang penting dalam upaya memerangi pekerja anak. Tetapi sikap pemerintah terhadap masalah ini bervariasi. Beberapa pemerintah berpura-pura menunjukkan minat untuk mengatasi masalah ini ketika ada tekanan internasional yang menimbulkan rasa malu.

Selain perlindungan hukum yang belum maksimal, Pemko Batam juga belum maksimal dalam menerapkan penegakan hukum, sebagaimana teori yang dikemukan oleh Soerjono Soekanto ${ }^{21}$ bahwa faktor yang

21 Soerjono Soekanto, 2004, Faktor-Faktor yang Mempengaruhi Penegeakan Hukum, Cetakan Kelima, Raja Grafindo Persada, Jakarta, Hlm. 42 
mempengaruhi penegakan hukum meliputi hukumnya sendiri, penegak hukum, sarana atau fasilitas, masyarakat, kebudayaan, berdasarkan hasil penelitian dilapangan, maka faktor-faktor tersebut diatas dapat diuraikan sebagai berikut:

a. Faktor hukumnya sendiri

Perlu peraturan pelaksana dari Undang-Undang Nomor 13 Tahun 2003 tentang Ketenagakerjaan yang mengatur khusus tentang perlindungan hukum terhadap pekerja anak, namun dalam hal ini Pemko Batam sampai saat ini belum mengeluarkan produk hukum berupa Peraturan Daerah tentang Perlindungan Anak, sehingga tidak mempunyai wadah untuk mencari penyelesaian terhadap penyimpangan aturan hukum terhadap pekerja anak.

b. Faktor penegak hukum

Berbagai masalah sangat nyata dihadapi oleh Pemko Batam, salah satunya adalah tidak adanya Sumber Daya Manusia (SDM) sehingga mengakibatkan jumlah pegawai pengawas ketenagakerjaan yang ada kurang dari jumlah yang dibutuhkan. Di samping itu, pengawas pada umumnya menangani bidang kerja sektor formal, padahal sebagian besar pekerja anak justru terdapat di sektor informal.

c. Sarana atau fasilitas

Sarana hukum (yuridis instrument) dan sarana terhadap proses penyelesaian penyimpangan peraturan perundang-undangan terhadap pekerja anak di Kota Batam Belum ada, sehingga masyarakat (khususnya pekerja anak) yang menjadi korban pelanggaran hukum sulit mendapatkan perlindungan.

d. Masyarakat

Kenyataan yang terjadi di Kota Batam, angka kemiskinan semakin meningkat dari tahun ke tahun, hal ini mendorong munculnya pekerja anak dalam bentuk yang sangat exploitatif.

e. Kebudayaan

Budaya masyarakat di Indonesia khususnya Kota Batam bahwa orang tua memperbolehkan anak untuk bekerja adalah dalam kapasitas mendidik anak supaya terbiasa bekerja jika kelak si anak dewasa. Oleh karena itu, agar tidak terjadi salah asuh, salah arah dan tetap melindungi hak-hak anak, maka sangat perlu dijelaskan tentang kewajiban yang perlu dilakukan oleh anak dalam rangka belajar bekerja atau membantu orang tua.

\section{E. Kesimpulan}

Komitmen Yuridis negara untuk melindungi pekerja anak dituangkan dalam konstruksi hukum dengan dikeluarkannya peraturan perundangundangan yang pada prinsipnya melarang anak untuk bekerja dan apabila terpaksa bekerja, maka secara normatif anak-anak tersebut harus memperoleh jaminan perlindungan hukum yang memadai, pada dasarnya peraturan perundang-undangan ini merupakan sarana perlindungan hukum 
preventif yang dilakukan oleh pemerintah, akan tetapi pada pelaksanaannya penegakan hukum sebagaimana teori yang dikemukakan oleh Soerjono Soekanto bahwa faktor yang mempengaruhi penegakan hukum meliputi hukumnya sendiri, penegak hukum, sarana atau fasilitas, masyarakat, kebudayaan cenderung kurang efektif, sehingga praktek-praktek memperkerjakan anak sering kali terjadi.

Dalam perkembangannya anak dianggap suatu barang untuk menjadi suatu objek perjanjian antara agen dengan orang tua, dalam hal ini yang diperjanjikan adalah jasa dari penjualan koran yang dilakukan oleh pekerja anak. Ironisnya perusahaan media cetak sebagai produsen juga turut melakukan pembiaran atas adanya pekerja anak dalam transaksi penjualan koran, hal ini dikarenakan kurang tegasnya sanksi yang diberikan oleh perusahaan media cetak terhadap agen-agennya tentang larangan memperkerjakan anak, dengan pertimbangan turut memperkrjakan anak dalam transaksi penjualan koran dapat medongkrak jumlah (oplah) penjualan. Sedangkan perlindungan hukum secara preventif yang dilakukan oleh Pemko Batam hanya sebatas menerapkan peraturan perundangundangan produk dari pemerintah pusat. Sehingga dalam hal perlindungan hukum secara represif Pemko Batam belum memiliki sarana hukum (yuridis instrument) dan sarana proses yang mengatur tentang bagaimana tata cara penyelesaian terhadap penyimpangan peraturan perundang-undangan tehadap pekerja anak. 


\section{DAFTAR PUSTAKA}

\section{Buku}

Ahmadi, Abu, 1999, Psikologi Sosial, Rineka Cipta, Jakarta.

Gosita, Arif 1989, Masalah Perlindungan anak-Edisi Pertama, Akademi Presindo, Jakarta.

Firdaus, 2010, Pancasila, Suska Pers, Pekanbaru.

Huda, Miftachul, 2009, Pekerjaan Sosial dan Kesejahteraan Sosial, Sebuah Pengantar, Pustaka Pelajar, Yogyakarta.

Hadjon, Philipus M., 1987, Perlindungan Hukum Bagi Rakyat Indones, Bina Ilmu, Surabaya.

Soekanto, Soerjono, 1983, Teori Sosiologi Tentang Perubahan Sosial, Ghalia Indonesia, Surabay.

Sugiyono, 2008, Metode Penelitian Kuantitatif Kualitatif dan R\&D, Alfabeta, Bandung.

\section{Artikel/Jurnal}

Bahar, Saafroedin dkk., Risalah Sidang Badan Penyelidik Usaha-Usaha Persiapan Kemerdekaan (BPUPKI), Panitia Persiapan Kemerdekaan Indonesia (PPKI) 28 Mei 1945 - 33 Agustus 1945, Jakarta: Sekretariat Negara Republik Indonesia, 1995.

Raharjo, Satjipto, Penyelenggaraan Keadilan dalam Masyarakat yang Sedang Berubah, Jurnal Masalah Hukum, 1993.

\section{Sumber Internet}

BPS Kepri, Jumlah Penduduk Miskin per Kab./Kota, 2007 - 2011, (Jiwa) http://kepri.bps.go.id/tabel/ tabeltersimpan?kode=106, diakses tanggal 22 Oktober 2014.

Widodo, Anak Jalanan Berkeliaran di Batam, http://www.batamtoday.com/berita39068-Setidaknya-200-an-AnakJalanan-Berkeliaran-di-Batam.html, diakses tanggal 22 Oktober 2014.

http://www.batamtoday.com/berita39068-Setidaknya-200-an-Anak-JalananBerkeliaran-di-Batam.html, diakses tanggal 22 Oktober 2014

\section{Peraturan Perundang-undangan}

Undang-Undang Dasar Negara Republik Indonesia tahun 1945.

Kitab Undang-Undang Hukum Perdata (KUHPerdata).

Undang-Undang Republik Indonesia Nomor 39 Tahun 1999 tentang Hak Asasi Manusia (Lembaran Negara Republik Indonesia Tahun 1999

Nomor 165, Tambahan Lembaran Negara Republik Indonesia Nomor 3886). 
Undang-Undang Republik Indonesia Nomor 23 Tahun 2002 tentang Perlindungan Anak (Lembaran Negara Republik Indonesia Tahun 2002 Nomor 109, Tambahan Lembaran Negara Republik Indonesia Nomor 4235).

Undang-Undang Republik Indonesia Nomor 13 Tahun 2003 tentang Ketenagakerjaan (Lembaran Negara Republik Indonesia Tahun 2003 Nomor 39, Tambahan Lembaran Negara Republik Indonesia Nomor 4279).

Undang-Undang Republik Indonesia Nomor 35 Tahun 2014 tentang Perubahan Undang-Undang Republik Indonesia Nomor 23 Tahun 2002 tentang Perlindungan Anak (Lembaran Negara Republik Indonesia Tahun 2014 Nomor 297, Tambahan Lembaran Negara Republik Indonesia Nomor 5606)

Keputusan Presiden Nomor 36 Tahun 1990 tentang pengesahan Konvensi Hak-hak Anak. 